\title{
Infecção latente de Didymella bryoniae em meloeiro nobre
}

\author{
Francielli Gasparotto $^{1,2}$, João Batista Vida ${ }^{1}$, Dauri José Tessmann ${ }^{1}$, Tatiane Cristina Albuquerque Alves ${ }^{1}$
}

${ }^{1}$ Universidade Estadual de Maringá, Departamento de Agronomia, Av. Colombo, 5790, 82020-900, Maringá-PR; ${ }^{2}$ Bolsista Capes; ${ }^{3}$ Bolsista CNPq. Parte da tese de doutorado do primeiro autor.

Autor para correnpondência: João Batista Vida (jbvida@uem.br)

Data de chegada: 23/07/2009. Aceito para publicação em: 25/01/2011.

\section{RESUMO}

Gasparotto, F.; Vida, J.B.; Tessmann, D.J.; Alves. T.C.A. Infecção latente de Didymella bryoniae em meloeiro nobre. Summa Phytopathologica, v.37, n.1, p.62-64, 2011.

Didymella bryoniae, agente causal da podridão gomosa, é um importante patógeno em meloeiro nobre, em cultivo protegido e recentemente, resultados de alguns trabalhos têm evidenciado a ocorrência de infecção latente de $D$. bryoniae em meloeiro, sem, no entanto, registrar a comprovação. Objetivou-se com este trabalho constatar a ocorrência de infecção latente de $D$. bryoniae, em plantas dos híbridos de meloeiro nobre Sunrise, Bônus II e Prince Hakucho assintomáticas. Empregou-se a técnica de reação da polimerase em cadeia (PCR), com o conjunto de 'primers' D7S, D6 e UNLO28822, que amplificam regiões do DNA e distinguem D. bryoniae de outras espécies similares e de outros microrganismos comuns. Em todos os híbridos testados, constatou-se a presença de $D$. bryoniae no caule de plantas assintomáticas, através da amplificação das regiões específicas delimitadas pelos 'primers' utilizados.

Palavras-chave adicionais: Podridão gomosa, Cucumis melo.

\section{ABSTRACT}

Gasparotto, F.; Vida, J.B.; Tessmann, D.J.; Alves. T.C.A.. Latent infection by Didymella bryoniae in muskmelon. Summa Phytopathologica, v.37, n.1, p.62-64, 2011.

The causal agent of gummy stem blight, Didymella bryoniae, is an important pathogen for Cucurbitaceae species and has been the main source of biotic and infectious damages to muskmelon under protected cultivation. Some recent studies have evidenced the occurrence of latent infections by $D$. bryoniae in melons, but without confirmation. Thus, the present study aimed to the occurrence of latent infection by Didymella bryoniae in asymptomatic plants of the muskmelon hybrids Sunrise, Bonus II and Prince Hakucho through polymerase chain reaction (PCR) using the set of primers D7S, D6 and UNLO28822, which amplify DNA regions capable of distinguishing $D$. bryoniae from other similar species and common microorganisms. In all tested hybrids, the presence of D. bryoniae was confirmed in the stems of asymptomatic plants through amplification of specific regions delimited by the employed primers.

Palavras-chave adicionais: Gummy stem blight, Cucumis melo.

A podridão gomosa, causada por Didymella bryoniae (Fuckel) Rehm é a mais devastadora doença em meloeiros nobres (Cucumis melo var. reticulatus e C. melo var. cantalupensis) em cultivo protegido no Estado do Paraná, podendo causar danos de até $100 \%(5 ; 6)$. O patógeno pode estar associado às sementes, superficialmente ou no seu interior (4) e a importância da infecção de sementes não está apenas na possibilidade do desenvolvimento em larga escala da doença, mas também na introdução do inóculo em áreas não infestadas. Resultados de trabalhos desenvolvidos recentemente evidenciaram sem comprovação, que $D$. bryoniae originada de sementes pode apresentar infecção latente em plantas de meloeiro. A primeira referência da possibilidade de infecção latente de $D$. bryoniae em cucurbitáceas foi relatada por Vida et al. (7). Gasparotto (1) trabalhou com o mesmo patossistema, também observaram evidências que mudas de meloeiro infectadas permaneceram assintomáticas durante a fase de produção de mudas e os sintomas da doença só manifestaram após o transplante definitivo para o solo da estufa.

Um dos maiores problemas da ocorrência de infecção latente é a dificuldade de diagnose precoce da doença, pela ausência de sintomas, o quê pode resultar na adoção tardia de medidas de controle, comprometendo a sua eficiência. Para D. bryoniae, a grande importância da possível infecção latente de inoculo, originário de sementes, são as implicações na epidemiologia da doença na cultura de meloeiro nobre, em ambiente protegido. Segundo Vida et al. (6), o patógeno pode ser disseminado, eficientemente, por instrumental de poda e resultar em severas epidemias na cultura, com ocorrência de danos de até $100 \%$. Assim, este trabalho teve como objetivo constatar a infecção latente de $D$. bryoniae em plantas de meloeiro nobre, com inóculo originado de sementes.

A partir de sementes comerciais, plantas dos híbridos de meloeiro nobre Sunrise, Bonus II e Prince Hakucho foram produzidas em substrato comercial autoclavado em condições de casa-de-vegetação. Após 40 dias da emergência, plantas assintomáticas, plantas com sintomas de podridão gomosa e plantas sintomáticas com corpos de frutificação do patógeno foram coletadas para extração de DNA total. A extração do DNA total foi realizada de acordo com a metodologia 


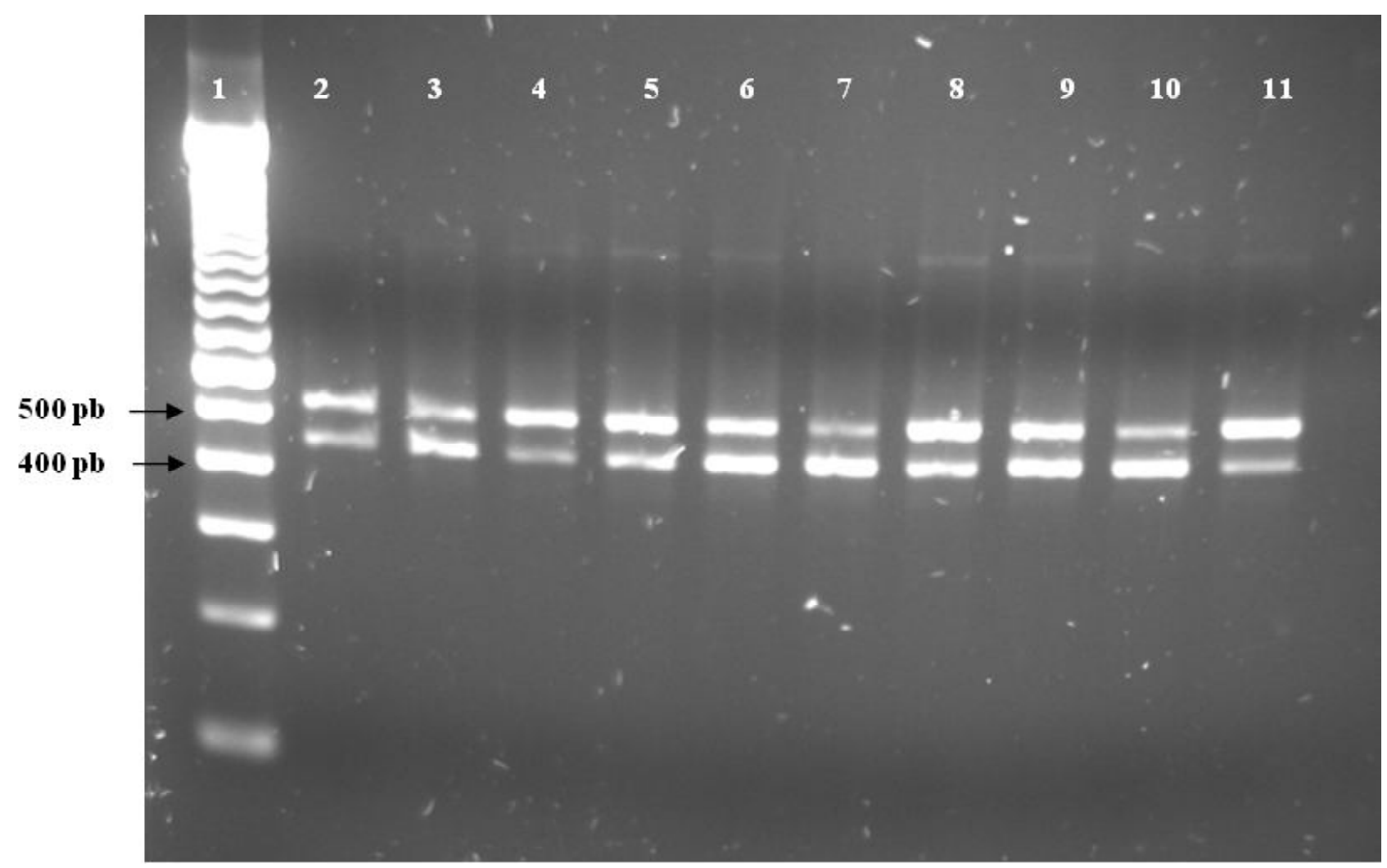

Figura 1. Gel de eletroforese apresentando especificidade na reação múltipla para Didymella bryoniae. 1- 100-pb ladder; hibrido Prince Hakucho: 2Plantas assintomáticas, 3- Plantas sintomáticas, 4- Plantas sintomáticas com corpos de frutificação; híbrido Bonus II: 5- Plantas assintomáticas, 6Plantas sintomáticas, 7- Plantas sintomáticas com corpos de frutificação; híbrido Sunrise: 8- Plantas assintomáticas, 9- Plantas sintomáticas, 10- Plantas sintomáticas com corpos de frutificação; 11- Isolado de D. bryoniae.

descrita por Koening et al. (2). Utilizou-se caules de cinco plantas de cada tratamento de cada híbrido. Para a constatação de D. bryoniae, a partir do DNA extraído das plantas, foram empregados os 'primers' específicos D7S (5'-CTACAATTGCGGGCTTTGC); D6 (5'CGCCGATTGGACAAAACTTAAA) e UNLO28S22 (5'GTTTCTTTTCCTCCGCT TATTGATATG) em reação múltipla (3). Estes 'primers' amplificarão bandas de 535 pb (UNLO28S22 + D7S) e 461 pb (UNLO28S22 + D6) na presença do patógeno. A reação de PCR (reação da polimerase em cadeia) foi baseada em 31 ciclos, sendo: 45 s a $94{ }^{\circ} \mathrm{C} ; 45$ s $63^{\circ} \mathrm{C}$; e 45 s a $72^{\circ} \mathrm{C}$. Previamente aos ciclos, as amostras foram submetidas à temperatura de $94^{\circ} \mathrm{C}$ por um minuto, e a um período extra de extensão de 10 min a $72{ }^{\circ} \mathrm{C}$ após os 31 ciclos. As reações de amplificação foram conduzidas em um termociclador T personal Whatman Biometra (Biometra $\mathrm{GmbH}$, Goettingen, Alemanha). Os produtos de PCR foram submetidos à eletroforese em gel de agarose $2 \%$, corado com brometo de etidio e iluminado com luz UV.

Os resultados mostraram que em plantas de todos os híbridos analisados, assintomáticas e sintomáticas, foi constatada a presença de D. bryoniae, pois ocorreu a amplificação das regiões do DNA que distinguem $D$. bryoniae de outras espécies similares e de outros microrganismos comuns (Figura 01).

O grande problema da ocorrência de infecção latente deste patógeno é que as plantas de meloeiro infectadas podem não manifestar sintomas na fase de produção de mudas, dificultando o seu descarte antes do transplante para a estufa. Segundo Gasparotto (1), mudas com infecção latente transplantadas, dentro de 15 dias pós-transplante, manifestam sintomatologia de podridão gomosa. Ainda segundo a autora, analisando sementes de meloeiros nobres cultivados no Brasil, dependendo do híbrido, a porcentagem de transmissão, com possível ocorrência de infecção latente, pode chegar a $59 \%$. Há presença de grande quantidade de inóculo no início do cultivo, geralmente resulta em severas epidemias e/ou baixa eficiência de medidas de controle $(1,6)$.

A hipótese de que o patógeno $D$. bryoniae pode causar infecção latente em plantas de meloeiro nobre foi confirmada, pois constatouse a formação de bandas originadas pelos conjuntos de 'primers' específicos e o DNA extraído das plantas assintomáticas.

\section{REFERÊNCIAS BIBLIOGRAFICAS}

1. Gasparotto, F. Avaliação da sanidade de sementes de híbridos de meloeiro nobre indicados para cultivo protegido. 2006. 42 f. Dissertação (Mestrado em Agronomia) - Universidade Estadual de Maringá, Maringá.

2. Koenig, R. L.; Ploetz, R. C.; Kistler H. C. Fusarium oxysporum f. sp. cubense consists of a small number of divergent and globally distributed clonal lineages. Phytopathology, St. Paul, v.87, n.9, p.915-923, 1997.

3. Koch, C.A.; Utkhede, R.S. Development of a multiplex classical polymerase chain reaction technique for detection of Didymella bryoniae in infected cucumber tissues and greenhouse air samples. Canadian Journal of Plant Pathology, Burnaby, v.26, n.3, p. 291-298, 2004.

4. Lee, H.; Mathur, S. B.; Neergaard, P. Detection and location of seed-borne inoculum of Didymella bryoniae and its transmission in seedlings of cucumber and pumpkin. Phytopathologische Zeitschrift, Berlin, v.109, p.301-308, 1984. 
5. Vida, J. B., Souto, E. R.; Nunes, W. M. C. Perdas causadas por Mycosphaerella melonis na cultura do melão em estufas plástiCas Fitopatologia Brasileira, Brasília, v. 18, p.324, 1993.

6. Vida, J. B.;Tessmann, D. J.; Zambolim, L.; Verzignassi, J. R.; Brandão Filho, J. U. T. Controle da podridão gomosa em melão rendilhado em cultivo protegido por sanitização de ferramenta de poda. Fitopatologia Brasileira, Lavras, v.29, p.626-630, 2004.

7. Vida, J. B.; Tessmann, D. J.; Brandão Filho, J. U. T.; C, Nunes W. M. Provável transmissão de Didymella bryoniae por sementes de melão rendilhado em cultivo protegido. In: Simpósio Brasileiro de Patologia de Sementes, 7., 2002, Sete Lagoas. Resumos e Palestras. Sete Lagoas: Embrapa Milho e Sorgo, 2002. p.79. 